\title{
IMPLEMENTASI UNDANG-UNDANG NO. 20 TAHUN 2008 DALAM PENGEMBANGAN USAHA PERIKANAN BERKELANJUTAN
}

\author{
Nur Sulistyo Budi Ambarini \\ Fakultas Hukum Universitas Bengkulu \\ ambarini@unib.ac.id
}

\begin{abstract}
In a system of sustainable fisheries businesses, MSMEs (Micro Small and medium enterprises) is one component that can not be ignored. Fisheries business system which includes pre-production, production, fishery product processing (post harvest) and the marketing done by many SMEs. Focus Act. 20 of 2008 on Micro, Small and Medium Enterprises (MSMEs) issued substantially in order to support the empowerment of SMEs which are not considered optimal, including the fisheries sector. By using the approach of socio-legal studies, the results of this study concluded that the implementation of Law no. 20 of 2008 relating to fisheries sector development of SMEs, yet reflect the expected conditions in the MSME Act, and yet provide a sense of justice, especially for micro and small enterprise sector.
\end{abstract}

Keywords: Implementation, Act, Fishery, Enterprise, Sustainable

\begin{abstract}
ABSTRAK
Dalam sistem bisnis perikanan yang berkelanjutan, UMKM (Usaha Mikro Kecil dan menengah) merupakan salah satu komponen yang tidak dapat diabaikan. Sistem bisnis perikanan meliputi pra-produksi, produksi, pengolahan hasil perikanan (pasca panen) dan pemasaran yang dilakukan oleh banyak Usaha Kecil dan Menengah (UKM). Berdasarkan Undang-Undang No. 20 Tahun 2008 tentang Usaha Mikro, Kecil dan Menengah (UMKM) yang secara substansial dikeluarkan dalam rangka mendukung pemberdayaan UKM yang dianggap belum optimal, termasuk sektor perikanan. Dengan menggunakan pendekatan studi sosio-legal, hasil penelitian ini disimpulkan bahwa pelaksanaan UU No. 20 tahun 2008 yang berkaitan dengan pengembangan sektor perikanan UKM, belum mencerminkan kondisi yang diharapkan dalam UU UMKM, dan belum memberikan rasa keadilan, terutama untuk sektor usaha mikro dan kecil.
\end{abstract}

Kata Kunci : Implementasi, Undang-Undang, Usaha, Perikanan, Berkelanjutan 


\section{PENDAHULUAN}

\section{Pembangunan}

berkelanjutan merupakan upaya untuk mensinergikan aspek ekonomi, sosial dan ekologi dalam proses pembangunan nasional. Pelaksanaannya perlu dilakukan dengan melibatkan semua pihak baik pemerintah, dunia usaha dan masyarakat. UMKM (Usaha mikro kecil dan menengah) merupakan salah satu komponen yang tidak dapat diabaikan keberadaannya dalam proses pembangunan ekonomi. UMKM adalah kelompok pelaku ekonomi yang jumlahnya hampir 50 juta unit $(99,84 \%)$ dari total usaha nasional. Menciptakan lapangan kerja sebesar 96\% dari total tenaga kerja. $^{1}$ Memiliki potensi sebagai penggerak ekonomi riil dan merupakan komponen esensial dalam pembangunan ramah lingkungan hidup. UMKM banyak bergerak dalam bidang pemanfaatan sumberdaya alam dan padat karya, salah satunya sektor perikanan.

1 Andi Irawan \& Bayu Erlangga Putra. Kewirausahaan UKM, Pemikiran dan Pengalaman, Yogyakarta: Graha Ilmu, Ed. 1, Cet. 1, 2007, hlm. 100-103.
Data statistik tahunan FAO yang dilaporkan oleh Infofish Fishing Technology Digest for Asia Pasific, edisi Juli-September 2004, menyebutkan Indonesia menempati urutan kelima sebagai produsen ikan terbesar setelah China, Peru, Amerika Serikat, dan Jepang. Produksi rata-rata meningkat sekitar $7 \%$ per tahun, dari 3.986.919 ton tahun 1999 menjadi 4.203.803 ton pada tahun 2001. Peningkatan ini terutama terjadi pada subsektor perikanan tangkap. Hal telah memberikan sumbangan bagi pertumbuhan perekonomian nasional. Tetapi di sisi lain, menimbulkan tekanan eksploitasi terhadap sumber daya ikan. Selain over fishing, juga menimbulkan

kerusakan ekosistem perairan laut.

Perikanan adalah salah
satu sektor primer. ${ }^{2}$ Usaha
perikanan merupakan aktivitas

2 Yuswar Zainul Basri, Bunga Rampai Pembangunan Ekonomi Pesisir, Jakarta: Penerbit Universitas Trisakti, Cet.2, 2007, hlm15; Sepuluh sektor tersebut adalah perikanan tangkap, perikanan budidaya, industri pengolahan hasil perikanan, industri bioteknologi, pertambangan dan energi, pariwisata bahari, transportasi laut, industri dan jasa maritim, pembangunan pulau-pulau kecil dan sumberdaya nonkonvensional (nonconventional resources). 
pemanfaatan sumber daya ikan untuk kebutuhan konsumsi dalam negeri ataupun sumber devisa. Usaha ini merupakan kegiatan ekonomi kelautan yang meliputi kegiatan pra produksi, produksi, pengolahan hasil perikanan (pasca panen) dan pemasaran. Sedikitnya terdapat sepuluh sektor ekonomi kelautan yang memiliki prospek bisnis cerah yang dapat dikembangkan untuk memajukan dan memakmurkan Indonesia. ${ }^{3}$

Sektor perikanan, banyak dilakukan oleh usaha skala UMKM. Dilihat dari potensi sumber daya alam maupun penyerapan tenaga kerja, sektor ini terutama industri pengolahan hasil perikanan sangat potensial untuk dikembangkan. Industri pengolahan hasil perikanan termasuk salah satu industri pangan. Sifat produk yang dihasilkan merupakan sumber bahan pangan bagi manusia. Oleh karena itu pengembangan sektor ini, selain dapat mendukung memenuhi kebutuhan pangan dalam negeri juga kebutuhan ekspor untuk peningkatan devisa negara.

${ }^{3}$ Ibid.
Sementara di sisi lain, industri pengolahan hasil perikanan juga mempunyai potensi merusak lingkungan pesisir maupun laut.

Data dari Badan Pengendalian Dampak Lingkungan Daerah Propinsi Jawa timur (2003) menunjukan bahwa limbah dari industri pangan (termasuk pengolahan hasil perikanan) mempunyai presentase terbesar dari kumulatif limbah cair yang dibuang ke sungai dan akhirnya bermuara ke laut. ${ }^{4}$ Meski sebagian limbah industri pengolahan perikanan dapat diolah menjadi produk samping, tetapi terdapat juga limbah (padat/cair) yang terbuang dan menjadi penyebab pencemaran lingkungan disekitarnya.

Limbah industri pengolahan hasil perikanan tidak hanya dihasilkan oleh industri besar saja tetapi juga industri berskala UMKM. Limbah yang dihasilkan oleh industri skala UMKM biasanya tidak dilakukan penanganan khusus tetapi langsung dibuang ke selokan/sungai disekitar tempat

${ }^{4}$ Mukhtasor, Pencemaran Pesisir dn Laut. Jakarta: PT. Pradnya Paramita, Cet.1, 2007, hlm. 151. 
usaha. Secara komulatif berpotensi mencemari/merusak lingkungan yang dapat mempunyai dampak lingkungan cukup besar. Meski demikian menurut Otto Sumarwoto, dengan berlandaskan konsep ADS (Atur Diri Sendiri) proses pembangunan ekonomi yang berkelanjutan dapat dilakukan melalui pengembangan UMKM. ${ }^{5}$ Oleh karenanya UMKM yang realitanya memiliki modal terbatas, dapat dikembangkan untuk mendukung pembangunan yang berkelanjutan dan ramah lingkungan.

Pembangunan berkelanjutan (Sustainable

5 Otto Soemarwoto.Atur Diri Sendiri Paradigma Baru Pengelolaan Lingkungan Hidup. Yogyakarta: Gajah Mada University Press, Cet.2, 2001, hlm.152-153. Makna ADS adalah tanggungjawab menjaga kepatuhan dan penegakan hukum lebih banyak ditanggung oleh masyarakat, yang dipelopori oleh dunia usaha. Konsep ADS merupakan pendekatan alternatif dalam sistem pengelolaan lingkungan hidup yang bersifat memberi insentif dan disinsentif. Instrumen insentif-disinsentif (IID) diciptakan masyarakat sendiri, Masyarakat mengatur sikap dan kelakuannya sendiri, sehingga lebih mudah untuk diinternalkan sebagai nilai sosial masyarakat dan menjadi sarana kontrol sosial yang efektif. Dengan konsep ADS dikembangkan strategi bisnislingkungan hidup yang terintegrasi. Internalisasi lingkungan hidup bukan lagi suatu yang merugikan bisnis tetapi sebaliknya justru menguntungkan karena bisnis menjadi 'ramah lingkungan hidup.
Development) mengandung makna pembangunan yang memenuhi kebutuhan generasi sekarang tanpa mengurangi kemampuan generasi yang akan datang untuk memenuhi kebutuhannya. Pengertian tersebut diterjemahkan secara harfiah dari definisi oleh WCED (The World Commission on Environment and Development) dalam Our Common Future: "Development that meets the needs of the present whitout comprosing the ability of the future generation too meet their own needs". ${ }^{6}$

Konsep pembangunan berkelanjutan merupakan dasar pelaksanaan pembangunan di Indonesia. Hal ini telah tercantum di dalam Pasal 33 Undang-Undang Dasar Negara RI 1945, sebagai landasan

6 The World Commission on Environment and Development, Brundtland Commission, 1987, daiam Anup Shah,Sustainable Development Introduction, May, 26, 2005, diunduh dari www.globalissues.org, tanggal 25 Maret 2009, 06.43; lihat juga Ambar Teguh Sulistiyani, Kemitraan dan Model-Model Pemberdayaan. Yogyakarta: Gaya Media, Ed.1.Cet.1, 2004, hlm. 64; lihat juga; Mas Achmad Santosa, Good Governance dan Hukum Lingkungan. Jakarta: ICEL, 2001, hlm. 161; lihat juga WCED, Hari Depan Kita Bersama (Our Common Future). Jakarta: Gramedia, 1988, hlm. 58. 
pembangunan ekonomi. Dan juga dalam berbagai peraturan perundang-undangan sebagai salah satu asas. Dalam UndangUndang No. 20 Tahun 2008 tentang Usaha Mikro, Kecil, dan Menengah (UMKM), Pasal 2 huruf (e,f) ; dan Undang-Undang No. 31 Tahun 2004 tentang Perikanan, Pasal 2. Tetapi realitasnya pembangunan di berbagai bidang umumnya belum konsisten menerapkan konsep pembangunan berkelanjutan. Berbagai kendala baik dari aspek yuridis maupun non yuridis menjadi penyebabnya.

Secara umum substansi Undang-Undang No. 20 Tahun 2008 menjadi landasan dalam upaya pemberdayaan dan pengembangan UMKM. Fokus penelitian ini antara lain bagaimana implementasi ketentuan Undang-Undang UMKM dalam pelaksanaan pengembangan UMKM sektor perikanan yang berkelanjutan? Oleh sebab itu penelitian ini bertujuan untuk mengetahui dan mengkaji implementasi ketentuan Undang-Undang No. 20 Tahun 2008 alam pengembangan UMKM sektor perikanan terkait dengan konsep pembangunan berkelanjutan.

\section{METODE PENELITIAN}

Penelitian ini merupakan penelitian hukum dalam ranah kajian socio-legal Studies, karena dalam penelitian ini hukum dikonsepsikan sebagai a set of rules yang mengatur dan mengendalikan sistem masyarakat. Lokasi Penelitian ini ditentukan Kabupaten Banyuwangi yang merupakan salah satu sentra perikanan. Sumber data: bahan hukum (primer, sekunder) dan data primer, data sekunder; Pengumpulan data: observasi, wawancara;

\section{PEMBAHASAN}

Pengaturan UMKM dalam Undang-Undang No. 20 Tahun 2008 berfokus pada upaya pemberdayaan yang lebih terintegrasi antara usaha mikro, kecil dan menengah, sehingga dapat eksis dan mampu berkembang secara mandiri dan optimal. Pendekatan pemberdayaan terhadap UMKM 
mempunyai arah dan orientasi yang berbeda-beda sesuai karakteristiknya, yaitu: (a) Fokus Usaha Mikro, kepada penanggulangan

pengangguran, kemiskinan, gender, kesenjangan dan keadilan untuk mengakses sumber daya produktif; (b) Usaha Kecil, difokuskan kepada dorongan untuk mewujudkan ketangguhan usaha kecil dan terbukanya investasi kepada mereka serta penumbuhan kemandirian dan kemampuan berkiprah di Pasar; (c) Usaha Menengah, difokuskan kepada pertumbuhan dan kemampuan mengakses pasar ekspor.

\section{Substansi Undang-Undang}

No. 20 Tahun 2008 yang berkaitan dengan dasar pemberdayaan UMKM. Alam Undang-Undang ini terdapat sembilan (9) asas UMKM yang tercantum pada Pasal 2. Konsep Pembangunan berkelanjutan tersurat dalam Pasal 2 huruf (e) dan (f) sebagai salah satu asas pemberdayaan UMKM. Demikian juga dalam UndangUndang No. 31 Tahun 2004 jo Undang-Undang No. 45 Tahun
2009 tentang Perikanan. "Asas berkelanjutan" adalah asas yang secara terencana mengupayakan berjalannya proses pembangunan melalui pemberdayaan UMKM yang dilakukan secara berkesinambungan sehingga terbentuk perekonomian yang tangguh dan mandiri. Sedangkan "asas berwawasan lingkungan" adalah asas pemberdayaan UMKM yang dilakukan dengan tetap memperhatikan dan mengutamakan perlindungan dan pemeliharaan lingkungan hidup.

Pilar utama Pembangunan berkelanjutan adalah aspek ekonomi, lingkungan hidup dan sosial. Inti pembangunan berkelanjutan adalah pembangunan ekonomi yang harus berwawasan lingkungan dan sekaligus mengusahakan pemerataan seadil-adilnya, dan pembangunan yang dilakukan juga harus bersifat holistik. Menurut Sonny Keraf, ada tiga prinsip utama pembangunan berkelanjutan yang menjamin agar ketiga aspek pembangunan dipenuhi. Ketiga aspek hanya 
mungkin dicapai apabila ketiga prinsip dasar yaitu (a) prinsip demokrasi; (b) prinsip keadilan; (c) prinsip keberlanjutan, dioperasionalkan dalam politik pembangunan. ${ }^{2} \quad$ Sementara Yakobs, dkk, mengajukan empat prinsip untuk mencapai pembangunan berkelanjutan yaitu pemenuhan kebutuhan dasar (fulfilment of human needs), pemeliharaan lingkungan (maintenance of ecological integrity), keadilan sosial (social equity), dan kesempatan untuk menentukan nasib sendiri (self determination). ${ }^{7}$

7 A Sony Keraf, Op.Cit, hlm. 175180- Prinsip demokrasi, yang menjamin agar pembangunan dilaksanakan sebagai perwujudan kehendak seluruh rakyat demi kepentingan bersama seluruh rakyat; (b) prinsip keadilan, yang menjamin bahwa semua orang dan kelompok masyarakat memperoleh peluang yang sama untuk ikut dalam proses pembangunan dan kegiatan-kegiatan produktif serta ikut dalam menikmat hasil-hasil pembangunan; (c) prinsip keberlanjutan, yang mengharuskan untuk merancang agenda pembangunan dalam dimensi visioner jangka panjang, untuk melihat dampak pembangunan baik positif maupun negative dalam segala aspeknya . Untuk mencapai pembangunan yang demokratis, berkeadilan, dan berkelanjutan, membutuhkan proses panjang. Dan untuk itu dibutuhkan kemitraan dalam semangat saling memahami dan saling percaya yang positif-konstruktif diantara berbagai stakeholders Keberhasilan pembangunan berkelanjutan memerlukan sinergi positif
Konsep

perikanan

berkelanjutan

(sustainable

fisheries) pada intinya konsep ini tidak terlepas dari prinsipprinsip konsep pembangunan berkelanjutan (sustainable development. Paradigma sosial dan komunitas (community paradigm), yang dikembangkan oleh Anthony T Charles (2001), 8 keberlanjutan sumberdaya dicapai melalui pendekatan kemasyarakatan. Artinya, keberlanjutan sumberdaya diupayakan dengan memberi perhatian utama pada aspek keberlanjutan masyarakatnya sebagai sebuah sistem komunitas. Perikanan yang berkelanjutan tidak hanya ditujukan untuk kepentingan kelestarian sumber daya ikan atau keuntungan ekonomi semata, tetapi juga untuk keberlanjutan komunitas perikanan (sustainable community). Keberlanjutan ini juga harus ditunjang oleh keberlanjutan institusi

antara tiga kekuatan utama yaitu Negara (kekuatan politik), sektor swasta (kekuatan ekonomi), dan masyarakat warga (kekuatan moral).

8 Sudharto P. Hadi, Dimensi Lingkungan Perencanaan Pembangunan, Yogyakarta: Gajah Mada University Press, Cet. 2, 2005, hlm. 6. 
(institutional sustainability) yang mencakup kualitas keberlanjutan dari perangkat regulasi, kebijakan, dan organisasi untuk mendukung tercapainya keberlanjutan ekologi, ekonomi dan komunitas perikanan.

Mengacu pada konsep tersebut dapat dikatkan bahwa konsep pembangunan berkelanjutan sebagai asas dalam Undang-Undang No. 20 Tahun 2008 tentang UMKM maupun dalm Undang-Undang No. 31 Tahun 2004 jo UndangUndang No. 45 tahun 2009 belum belum berjalan secara optimal. Hal tersebut dapat disimpulkan berdasarkan hasil penelitian, sebagai berikut: Dalam tabel 8 tentang Perkembangan Produksi Perikanan Tangkap Tahun 2004-2008 di lokasi penelitian, memperlihatkan perolehan ikan dari tahun ke tahun mengalami penurunan. Sumber-sumber ikan semakin rusak dan berkurang populasinya. Penurunan produksi perikanan diindikasikan oleh kerusakan terumbu karang, kerusakan hutan mangrove, dan lingkungan lainnya. kondisinya sangat kritis akibat maraknya penangkapan ikan dengan menggunakan bahan peledak jenis potasium dan banyaknya pencurian batuan karang sebagai campuran kapur. Selain itu juga peningkatan harga BBM sehingga mengurangi frekuensi melaut.

Dalam memanfaatkan sumber daya perikanan di selat Bali, telah dilakukan kesepakatan antara Propinsi Jawa Timur dan Propinsi Bali, dalam Keputusan Bersama Gubernur Kepala Daerah Tingkat I Jawa Timur dan Gubernur Kepala Daerah Tingkat I Bali Nomor : 238/674 Tahun 1992 , tanggal 14 Nopember 1992. Potensi penangkapan maksimum 46.400 ton/tahun dengan basis utama Muncar memiliki potensi sumberdaya perikanan utamanya lemuru. Potensi yang boleh ditangkap (agar berkelanjutan) $80 \%$ dari MSY sebesar 25.256 ton/tahun (PPIS-Unibraw, 2004). Sementara hasil produksi penangkapan sebesar 31.219,341 ton/tahun. 
Pemanfaatannya mencapai 123 $\%$ sehingga daerah ini sudah dinyatakan kelebihan tangkap (over fishing).

$\begin{array}{lcr}\text { Selain } & \text { itu di } & \text { lokasi } \\ \text { penelitian } & \text { terdapat } & \text { Unit } \\ \text { Pengolahan } & \text { Ikan } & \text { (UPI) } \\ \text { modern/semi } & \text { modern } & \text { dan }\end{array}$
tradisional, baik skala besar, menengah, kecil, maupun mikro/rumah tangga. Terdapat perusahaan pembekuan ikan, pengalengan dan penepungan ikan, serta minyak ikan skala besar (PT) 46 unit dan 72 unit UMKM. Selain itu pengolahan hasil perikanan secara tradisional seperti pengeringan/pengasinan ikan, pemindangan dan pengasapan kurang lebih 225 unit, yang sebagian besar adalah skala kecil dan mikro/rumah tangga.

Dalam operasional kegiatannya secara umum UPI belum memiliki IPAL termasuk perusahaan besar. Selain biaya yang cukup besar, alasan belum adanya IPAL adalah area lokasi yang padat sehingga belum memungkinkan untuk dibangun IPAL. Meskipun sebagaian limbah padat dan cair pengolahan hasil perikanan dapat di produksi untuk hasil samping. Sisanya tetap di buang di sekitar area pengolahan dan menjadi sumber pencemaran wilayah pesisir dan laut di lokasi penelitian.

Pelaku usaha perikanan di lokasi penelitian sebagian besar adalah skala mikro dan kecil baik pada tingkat produksi (nelayan/petani ikan) maupun pasca panen/pengolahan dan pemasaran hasil perikanan (Pengolah dan pedagang). Secara umum orientasinya masih sebagai matapencarian untuk mempertahankan hidup, memenuhi kebutuhan dasar sehari-hari.

Pasal 6 Undang-undang No. 20 Tahun 2008 mengatur mengenai kriteria UMKM. Mendasarkan pada kekayaan bersih (net asset) yaitu hasil pengurangan total nilai kekayaan usaha (aset) dengan total nilai kewajiban, tidak termasuk tanah dan bangunan tempat usaha. Dalam sistem bisnis perikanan, hal ini dijabarkan lebih lanjut dalam PP No. 54 Tahun 2002 tentang 
Usaha Perikanan; Peraturan Menteri Kelautan Dan Perikanan Nomor:

Per.18/Men/2006 Tentang

Skala Usaha Pengolahan Hasil Perikanan, dan Peraturan Menteri Kelautan Dan Perikanan Republik Indonesia Nomor Per.13/Men/2008 Tentang Skala Usaha Di Bidang Pembudidayaan Ikan.

\section{Pasal 7 Undang-Undang} No. 20 Tahun 2008, mengatur bahwa Pemerintah dan Pemerintah Daerah menetapkan perundang-undangan dan kebijakan meliputi aspek pendanaan, sarana dan prasarana, informasi usaha, kemitraan, perizinan usaha, kesempatan berusaha, promosi dagang, dan dukungan kelembagaan. Perbaikan dan penumbuhan ikim usaha yang kondusif terkait dengan aspek regulasi untuk memberikan kesempatan kepada masyarakat dan pelaku usaha untuk mengembangkan usaha dan mengakses sumber daya produktif.

$$
\text { Berkaitan dengan }
$$
kesempatan berusaha (Pasal 7 ayat (1) huruf (f) jo Pasal 13 Undang-Undang No. 20 Tahun 2008, ditujukan untuk menentukan peruntukan tempat usaha, mencadangkan bidang usaha termasuk melindungi usaha tertentu yang strategis untuk UMKM. Kepastian tempat usaha, diatur dalam Pasal 13 ayat (1) huruf (b) dan Pasal 7 ayat (1) huruf (f) terkait dengan kesempatan berusaha. Penentuan tempat usaha (lokasi) merupakan hal yang penting untuk memberikan kepastian tempat usaha bagi UMKM khususnya usaha mikro. Hal ini berhubungan dengan peruntukan tata ruang kota/daerah, sehingga perlu menjadi perhatian Pemerintah daerah.

Berdasarkan Keputusan Menteri Kelautan dan Perikanan: No. Kep.11/Men/2004 tentang Pelabuhan Pangkalan Bagi Kapal Perikanan, wilayah Muncar Kabupaten Banyuwangi ditetapkan sebagai Pelabuhan Perikanan Pantai. Demikian juga dalamKeputusan Menteri Kelautan dan Perikanan Nomor 
KEP.41/MEN/2009 tentang

Penetapan Lokasi Minapolitan, sebagai salah satu lokasi rencana pembangunan Minapolitan Perikanan Tangkap pada tahun 2013. Dan PERDA No. 29 Tahun 1993 tentang Rencana Detail Tata Ruang Kota (RDTRK) Muncar Tahun $1991 / 1992 \quad-\quad 2013 / 2014$, Fungsi dan peran utama Kota Muncar serta arah pengembangannya, salah satunya sebagai Pusat kegiatan hasil tangkapan ikan laut dan pendaratan ikan, yang berperan dalam berkembangnya kawasan industri pengolahan ikan.

Pencadangan bidang usaha terkait sektor perikanan terdapat dalam Peraturan Presiden Republik Indonesia Nomor 77 Tahun 2007 Tentang Daftar Bidang Usaha Yang Tertutup Dan Bidang Usaha Yang Terbuka Dengan Persyaratan Di Bidang Penanaman Modal dan Keppres No. 127 Tahun 2001 tentang Bidang / Jenis Usaha yang dicadangkan untuk Usaha Kecil dan Bidang/Jenis yang Terbuka untuk Usaha Menengah atau Besar dengan Syarat Kemitraan.
Bidang / Jenis usaha yang dicadangkan untuk Usaha Kecil, Sektor Kelautan dan Perikanan: Perikanan tangkap dengan menggunakan kapal kurang dan 30 GT/SOPK dilakukan di perairan sampai dengan 12 mil laut; Perikanan budidaya meliputi pembenihan dan pembesaran ikan di air tawar, air payau dan laut; Penangkapan Ikan Hias Air Tawar; Sektor Industri dan Perdagangan; Industri makanan dan minuman olahan yang melakukan : pengawetan dengan proses pengasinan, penggaraman, pemanisan, pengasapan, pengeningan, perebusan, penggorengan dan fermentasi dengan cara-cara tradisional. Bidang.Jenis Usaha yang terbuka bagi Usaha Menengah atau Usaha Besar dengan syarat kemitraan. Sektor Kelautan dan Perikanan: Perikanan budidaya meliputi pembesaran ikan kakap putih, kerapu, mutiara, bandeng, udang, labi-labi, nila, sidan dan kodok lembu.

Perizinan usaha diatur dalam Pasal 7 ayat (1) huruf (e) dan Pasal 12 UU No. 20 tahun 
2008. Persoalan perizinan merupakan salah satu masalah yang selalu dihadapi oleh UMKM terutama usaha mikro terkait dengan pengembangan usaha. Pasal 12 ayat (2) menyebutkan persoalan perijinan akan diatur dengan Peraturan pemerintah. Namun sampai saat ini belum terwujud. Dalam bidang perikanan khususnya di lokasi penelitian diatur dalam Peraturan Daerah Kabupaten Banyuwangi No. 12 Tahun 2002 tentang Usaha Perikanan. Formalisasi atau legalitas perusahaan maupun kegiatan usaha melalui bentuk perizinan, merupakan hal yang menjadi tuntutan berbagai pihak, termasuk lembaga pemerintah dalam kaitannya dengan kerjasama, kemitraan, pembinaan maupun pemberdayaan UMKM.

Terkait dengan perijinan, berdasarkan data dan wawancara di lapangan pada umumnya pelaku usaha terutama untuk usaha mikro dan kecil (sub sektor pengolahan dan pemasaran) tidak memiliki ijin usaha. Banyak pelaku usaha yang tidak mengurus perijinan usaha dengan alasan selain biaya cukup mahal, banyaknya persyaratan yang harus dipenuhi. Meskipun di wilayah lokasi penelitian telah diterapkan sistem perijinan terpadu, untuk ijin usaha perikanan masih harus dilakukan di Dinas Kelautan dan Perikanan, dengan berbagai persyaratan perijinan lainnya yang harus diurus di Badan Pelayanan Perijinan Terpadu.

Kemitraan diatur dalam Pasal 7 ayat (1) huruf (d) dan Pasal 11. Ketentuan ini memberikan peluang kepada UMKM untuk mewujudkan kemitraan antar UMKM, dan antara UMKM dan Usaha besar; serta mendorong terjadinya hubungan saling menguntungkan dalam pelaksanaan transaksi baik antar UMKM maupun antara UMKM dengan Usaha Besar. Hal ini penting terutama untuk mengembangkan posisi tawar UMKM, menjamin tumbuhnya persaingan sehat dan melindungi konsumen, serta mencegah penguasaan pasar 
dan pemusatan usaha perorangan atau kelompok.

Dalam bisnis masalah modal merupakan hal yang esensial. Salah satu persoalan yang dihadapi UMKM termasuk sektor perikanan adalah permodalan. Untuk membantu mengatasi persoalan tersebut, Pemerintah memberikan berbagai fasilitas pendanaan agar UMKM dapat mengakses kredit perbankan maupun lembaga keuangan lainnnya. Sesuai perintah Pasal 7 ayat (1) huruf (a) dan Pasal 8 UndangUndang No. 20 Tahun 2008, berbagai kebijakan dan program khususnya untuk sektor perikanan dikeluarkan Pemerintah dan Pemerintah Daerah.

Sejak $\begin{gathered}\text { tahun } \\ \text { Kementerian }\end{gathered}$ Kelautan dan
Perikanan telah melaksanakan
Program PEMP (Pemberdayaan
Ekonomi Masyarakat Pesisir).
Program ini merupakan salah
satu upaya untuk membantu
masyarakat pesisir termasuk
UMKM pada sektor perikanan.
Secara filosofi, program PEMP
untuk

pendapatan dan mengurangi beban hidup masyarakat pesisir. Peningkatan pendapatan dilakukan dengan antara lain melalui akses modal. Berdasarkan KepMen Kelautan dan Perikanan No.Kep-18-Men2004 tentang Pedoman Umum Pelaksanaan Program Pemberdayaan Ekonomi Masyarakat Pesisir, Program ini ditujukan kepada masyarakat pesisir seperti nelayan, pembudidaya/petani ikan, pengolah ikan, pedagang, pengelola SPDN/BBM, Jasa pariwisata dan lain-lain yang tergolong usaha skala mikro dan kecil.

Program PEMP telah dilaksanakan di berbagai daerah sampai dengan tahun 2007 termasuk di lokasi penelitian. Di beberapa daerah program ini dapat dilaksanakan sesuai yang ditargetkan, antara lain dengan terbentuknya koperasi pesisir yang memiliki unit-unit usaha seperti LKM (Lembaga Kredit Mikro), Kedai Pesisir dan SPDN (Solar Packed Dealer untuk Nelayan). Di lokasi penelitian, Program PEMP tidak dapat berjalan karena persoalan 
manajemen yang kurang baik, sehingga program ini tidak berlanjut. Selain Program PEMP, melalui pelaksanaan Proyek CoFish tahun 2001-2004 di lokasi penelitian dibentuk Lembaga Keuangan Masyarakat Pantai (LKMP). Lembaga ini memberikan akses kredit kepada masyarakat termasuk UMKM. Selama masa pelaksanaan proyek, lembaga ini dapat berjalan dengan baik. Tetapi setelah proyek selesai, LKMP tidak berkembang lagi meskipun secara formal fasilitas tersebut masih ada.

Selain program-program tersebut, Pemerintah juga memperluas akses permodalan untuk UMKM melalui Perbankan dengan mengeluarkan kebijakan Kredit Untuk Rakyat (KUR). Program KUR diluncurkan berdasarkan Inpres Nomor 6 tahun 2007 tanggal 8 Maret 2007 tentang Kebijakan Percepatan Sektor Riil dan Pemberdayaan UMKMK guna meningkatkan pertumbuhan ekonomi Indonesia; Kebijakan ini kemudian ditindaklanjuti dengan MoU antara Departemen
Teknis, Perbankan, dan Perusahaan Penjaminan yang ditandatangani pada tanggal 9 Oktober 2007; dan dikeluarkannya Peraturan Presiden nomor 2 tahun 2008 tanggal 26 Januari 2008 tentang Lembaga Penjaminan.

Untuk mempermudah akses perbankan bagi UMKM dikembangkan pula Program KKMB (Konsultan Keuangan Mitra Bank). Khusus sektor perikanan, untuk mengembangkan program ini dilakukan Kesepakatan Bersama antara Departemen Kelautan dan Perikanan dan Bank Indonesia No:02/MENKP/KB/IV/2009

No:11/1/GBI/DKBU tentang Pengembangan Konsultan Keuangan/Pendamping Usaha Mikro dan Menengah Mitra Bank Sektor Kelautan dan Perikanan. Kesepakatan ini kemudian ditinjaklanjuti dengan Perjanjian Kerjasama antara Direktorat Jendral Pengolahan dan Pemasaran Hasil Perikanan Departemen Perikanan dan Bank Indonesia tentang Pengembangan Konsultan Keuangan /Pendamping Usaha 
Mikro, Kecil dan Menengah

Mitra Bank (KKMB) dan

Penyusunan Buku Pola

Pembiayaan Produk/Jasa

Sektor Kelautan dan Perikanan Nomor:

PK.04/P2HP/HK.155/VIII/09 $11 / 1 /$ DKBU-PK.

Dalam pelaksanaannya terutama di lokasi penelitian, program tersebut belum dapat berjalan dengan baik. Berdasarkan wawancara di lapangan, bagi UMKM fasilitas kredit perbankan sulit diakses karena pesyaratan-persyaratan yang tidak mudah untuk dipenuhi oleh UMKM. Terutama persyaratan legalitas usaha dan agunan/jaminan yang tidak dimiliki sebagian besar UMKM. Selain itu tingkat kepercayaan bank pada UMKM sektor perikanan yang masih rendah terutama untuk perikanan laut. Meskipun dengan bantuan KKMB, bank tidak mudah memberikan kredit karena faktor-faktor lain seperti sifat sektor perikanan laut yang sangat tergantung pada musim, cepat rusak dan sebagainya; juga faktor budaya masyarakat.

\section{SIMPULAN}

Berdasarkan hasil penelitian dan pembahasan sebagaimana telah diuraikan pada bab sebelumnya, maka hasil penelitian ini dapat disimpulkan sebagai berikut:

Ketentuan Undang-Undang No. 20 Tahun 2008 tentang UMKM secara normatif telah diimplementasikan dalam berbagai kebijakan dan program pengembangan sektor perikanan. Tetapi penerapannya belum berlangsung secara optimal. Hal tersebut disebabkan berbagai faktor antara lain: Kondisi UMKM sektor perikanan terutama usaha mikro (UMI) dan usaha kecil (UK) secara umum merupakan suatu usaha produktif yang masih berorientasi untuk mempertahankan hidup dan memenuhi kebutuhan dasarnya. Berbagai keterbatasan UMKM dan kesulitan untuk mengakses fasilitas-fasilitas yang tersedia dalam pengembangan UMKM. Hal tersebut disebabkan selain ketidakmampuan UMKM juga karena pelaksanaan kebijakan 
dan program yang belum ramah terhadap kondisi UMKM.

\section{Belum} adanya keterpaduan dan koordinasi yang baik diantara lembagalembaga yang berkompeten dalam mensosialisasikan konsep pembangunan berkelanjutan berkaitan dengan pengembangan UMKM sektor perikanan, baik dalam bentuk kebijakan maupun program kegiatan. Ego sektoral dan kepentingan masing-masing institusi pembina lebih mendominasi dan menjadi orientasi dalam melaksanakan pengembangan UMKM daripada kepentingan UMKM.

\section{Berlakunya Undang-}

Undang No. 20 tahun 2008 tentang UMKM diharapkan dapat menjadi pedoman dan landasan hukum dalam pelaksanaan pengembangan UMKM secara umum termasuk sektor perikanan. implementasinya berkaitan pengembangan UMKM, belum mencerminkan kondisi yang diharapkan dalam UndangUndang UMKM, dan belum memberikan rasa keadilan terutama bagi usaha mikro dan usaha kecil. Pembinaan dan pengembangan lebih berorientasi untuk kepentingan peningkatan produk ekspor yang notabene lebih banyak dilakukan usaha menengah dan usaha besar.

\section{SARAN}

Berdasarkan hasil penelitian berlakunya UndangUndang No. 20 tahun 2008 tentang UMKM, dalam implementasinya belum memberikan implikasi positif bagi pengembangan UMKM sektor perikanan yang berkelanjutan. Oleh karena itu perlu adanya suatu mekanisme kebijakan dan program yang lebih komprehensif dalam mengimplementasikan kententuan Undang-Undang berkaitan dengan pengembangan UMKM sektor perikanan secara berkelanjutan

\section{UCAPAN TERIMA KASIH}

Pada kesempatan ini, peneliti menyampaikan ucapan terima kasih yang sebesarbesarnya kepada: Program Doktor Ilmu Hukum Pascasarjana Universitas Diponegoro, yang telah memberikan kesempatan kepada 


\begin{tabular}{|c|c|}
\hline peneliti untuk mengajukan & Perundang-undangan, \\
\hline penelitian melalui Program Hibah & Program \\
\hline Doktor Tahun 2010; Direktorat & Perencanaan, \\
\hline Pendidikan & Perikanan/ \\
\hline Kementerian & Kementerian Koperasi dan UK \\
\hline Nasional, yang telah memberikan & RI: Kepala Dinas Kelautan d \\
\hline pembiayaan & Perikanan \\
\hline penelitian ini; & Banyuwangi dan Kota Semar \\
\hline Kepala Biro Hukum, Direktur & Kepala Dinas Koperasi dan U \\
\hline (Direktorat Jendral & Kabupaten Banyuwangi dan \\
\hline Pengolahan Dan Pemasaran Hasil & n cemun nihs \\
\hline Perikanan) Kementerian Kelautan & telah membantu dan mem \\
\hline dan Perikanan RI; & informasi, data, dan sebaga \\
\hline Urusan Tata laksana KUKM, & elesaian pelaksa \\
\hline Peraturan & penelitian ini. \\
\hline
\end{tabular}

\section{DAFTAR PUSTAKA}

Ambar Teguh Sulistiyani, Kemitraan dan ModelModel Pemberdayaan. Yogyakarta: Gaya Media, Ed.1.Cet.1, 2004

Andi Irawan \& Bayu Erlangga Putra. Kewirausahaan UKM, Pemikiran dan Pengalaman, Yogyakarta: Graha Ilmu, Ed. 1, Cet.1, 2007

Anup Shah, Sustainable Development Introduction, May 26, 2005, diunduh dari www.globalissues.org tanggal 25 Maret 2009

A Sonny Keraf, Etika Bisnis, Yogyakarta: Kanisius, Cet. 2, 1998

Lingkungan. Jakarta: ICEL, 2001 Mukhtasor, Pencemaran Pesisir dn Laut. Jakarta: PT. Pradnya Paramita, Cet.1, 2007

Otto Soemarwoto.Atur Diri Sendiri Paradigma Baru Pengelolaan Lingkungan Hidup. Yogyakarta: Gajah Mada University Press, Cet.2, 2001

Sudharto P. Hadi, Dimensi Lingkungan Perencanaan Pembangunan, Yogyakarta: Gajah Mada University Press, Cet. 2, 2005

Mas Achmad Santosa, Good Governance dan Hukum 
Yuswar Zainul Basri, Bunga

Rampai Pembangunan

Ekonomi Pesisir, Jakarta:

Penerbit Universitas

Trisakti, Cet.2, 2007 